\title{
Morpho-anatomical characterization of secondary somatic embryogenesis in Azadirachta indica (Meliaceae)
}

\section{Caracterización morfo-anatómica de la embriogénesis somática secundaria en Azadirachta indica (Meliaceae)}

\author{
Maria Daniela Artigas Ramirez ${ }^{1,3}$ (D), Rafael Fernández Da Silva² (D)
}

1 Tokyo University of Agriculture and Technology (TUAT), United Graduate School of Agricultural Science, Department of Biological Production Science, Tokyo, Japan.

2 University of Carabobo, Faculty Experimental of Science and Technology, Department of Biology, Center of Applied Biotechnology (CBA), Valencia, Venezuela.

3 Author for correspondence: artigasdaniela@gmail.com

Cite as:

Artigas Ramirez, M. D. and R. Fernández da Silva. 2018. Morpho-anatomical characterization of secondary somatic embryogenesis in Azadirachta indica (Meliaceae). Acta Botanica Mexicana 122: 7-20. DOI: http://dx.doi.org/10.21829/abml22. 2018.1242

Received: April 16, 2017

Reviewed: June 26, 2017

Accepted: August 8, 2017.

First Online: October 3, 2017

Published: January 1st 2018.

DOI:

http://dx.doi.org/10.21829/abml22. 2018.1242

\section{ABSTRACT:}

Background and Aims: Meliaceae species are extremely recalcitrant during germination and in vitro processes. Therefore, this research focuses on characterization and optimization of a highly efficient system by secondary somatic embryogenesis in Azadirachta indica, which is an important step for enhancing secondary metabolite production and regeneration in recalcitrant species.

Material and Methods: Leaf and cotyledon sections were induced in MS medium supplemented with benzylaminopurine (BAP) alone, or combined with 1-naphthaleneacetic acid (NAA) and, abscisic acid (BA) with thidiazuron (TDZ).

Key results: Azadirachta indica developed primary somatic embryos with BAP. Shoot and root formation occurred at low concentrations of BAP, while somatic embryogenesis was favored under high levels of BAP or TDZ. Primary and secondary somatic embryos were evidenced continuously and asynchronously. The highest amount of somatic embryos was obtained with cytokinins. However, the concentration might be significant to differentiate between primary and secondary embryos. Moreover, the auxins are key for inducing histodifferentiation in embryos. Shoot induction occurred after transfer of the embryos to hormone-free MS medium. The shoots were rooted in MS1/2.

Conclusions: The secondary somatic embryos were distinguished and characterized during the whole process and the efficient system was established with cotyledon sections at short term, which offers several advantages such as the production of metabolites.

Key words: abscisic acid (BA), asynchronous embryogenesis, benzylaminopurine (BAP), cyclic somatic embryogenesis, thidiazuron (TDZ).

\section{RESUMEN:}

Antecedentes y Objetivos: Las especies de Meliaceae son extremadamente recalcitrantes durante la germinación y en los procesos in vitro. Por lo tanto, este estudio está enfocado en caracterizar y optimizar un sistema altamente eficiente de propagación a través de embriogénesis somática secundaria en Azadirachta indica, paso importante para la producción de metabolitos secundarios, la propagación o regeneración de estas especies recalcitrantes.

Materiales y Métodos: Las secciones de hojas y cotiledones fueron inducidos en medio MS suplementado con bencil-aminopurina (BAP) sola o combinada con ácido 1-naftalenacético (NAA) y ácido abscísico (BA) con tidiazuron (TDZ).

Resultados clave: Azadirachta indica desarrolla embriones somáticos primarios con BAP. La formación de tallos y raíces ocurre en bajas concentraciones de BAP, mientras la embriogénesis somática es favorecida a altos niveles de BAP o TDZ. Los embriones somáticos primarios y secundarios fueron evidenciados continuamente y sincrónicamente o asincrónicamente. Una gran cantidad de embriones somáticos fueron obtenidos con citoquininas. Sin embargo, la concentración tiene un rol importante en la diferenciación entre embriones primarios y secundarios. Además, las auxinas son la clave para inducir la histo-diferenciación en los embriones. La inducción de tallo ocurrió después de que los embriones somáticos se transfirieron a un medio libre de hormonas (MS). Estos tallos fueron enraizados con MS1/2. Conclusiones: Los embriones somáticos secundarios fueron distinguidos y caracterizados durante todo el proceso y el sistema fue establecido con segmentos de cotiledones en corto tiempo; esto ofrece oportunidades ventajosas como la producción de metabolitos.

Palabras clave: ácido abscísico (BA), bencil-aminopurina (BAP), embriogénesis asincrónica, embriogénesis somática cíclica, tidiazuron (TDZ). 


\section{INTRODUCTION}

Azadirachta indica A. Juss., commonly known as neem, is widely distributed and has a high value on different continents including Asia, Oceania and America, especially Caribbean countries (LUZ, 2001; Puri, 1999). It is a tree belonging to the Meliaceae family, which has multiple applications in the traditional and actual agricultural systems. It is characterized by being evergreen, fast-growing, the dense and oval-crown appearance, the woody and moderately thin stem, and the pervasive and extensive type of roots. Furthermore, this species has a large production of active compounds, such as defensive secondary metabolites against pathogens or parasites (Allan et al., 1999; Badu et al., 2006). However, those compounds are of the non-toxic type, and the most important active ingredient is the "azadirachtin" triterpenoid, which can be synthesized chemically or extracted by using a large amount of plant material, and can be found mainly in the seeds, with a concentration range of 50-4000 $\mathrm{mg} \mathrm{l}^{-1}$ (Isman et al., 1990; Akula et al., 2003). Additionally, $A$. indica is an important source of natural products such as pharmaceutical, agrochemical, flavor ingredients and other products (Tripathi and Tripathi, 2003; Morgan, 2009). In Caribbean countries, this plant is used as an ornamental, pest repellent and food for livestock. In the medical field, it has diverse functions such as a natural antibiotic, antifungal, antiviral or antiparasitic (Pietrosemoli et al., 1999). From the agricultural view, it has been used to reduce the feeding damage to different crops caused by insects or as phytopathogens that inhibit the growth of mycelia (Meisner et al., 1981; Sutherland et al., 2002; Alcalá et al., 2005; Tafur et al., 2007).

Conventionally, neem is propagated by seeds; however, these are highly recalcitrant and do not tolerate low temperatures. On the other hand, they present some disadvantages such as the genetic heterogeneity product of cross-pollination (Parrotta and Chaturvedi, 1994; Kundu, 1999). In vitro propagation methods are able to obtain clonal cell lines and minimize these disadvantages. There are reports regarding the in vitro regeneration of $A$. indica for proliferation of plants derived from explants including seeds (Murthy and Saxena, 1998; Wewetzer, 1998), anthers (Gautam et al., 1993), axillary shoots (Sharry et al., 2006), endosperm (Thomas and Chaturvedi, 2008) and zygotic embryos (Chaturvedi et al., 2004).

In our previous research, we established an efficient and short-term sustainable system for the plant regeneration of $A$. indica by somatic embryogenesis (Artigas and Fernández da Silva, 2015; Fernández et al., 2016). In the present research, we explain further details of the anatomical characterization during the induction and regeneration, through the secondary somatic embryogenesis which was evidenced continuously and synchronously or asynchronously. Accordingly, it is essential to know and clarify the efficiency of in vitro plant propagation and to improve plant programs for secondary metabolites production without affecting the diversity through deforestation, intense crop cultivation or harvesting.

\section{MATERIAL AND METHODS}

\section{Sampling and protocols}

In this study, the explants were the leaf sections without veins and cotyledons, which were collected from fruits of adult plants (1-2 $\mathrm{m}$ high) of $A$. indica. The trees are located at the University of Carabobo, Venezuela (Bárbula campus). The disinfection protocol was conducted as described by Artigas and Fernández da Silva (2015). Subsequently, the leaf sections or cotyledon segments of $1 \mathrm{~cm}^{2}$ were placed in Petri plates with induction medium. The callus induction and regeneration media were prepared as described by Artigas and Fernández da Silva (2015).

This protocol consists of the following steps. Induction medium: Murashige and Skoog's (MS) enriched with benzyl-aminopurine (BAP) at $2.5 \mathrm{mg} \mathrm{l}^{-1}$ alone, and BAP (1.0 $\left.\mathrm{mg} \mathrm{l}^{-1}\right)$ combined with 1-naphthaleneacetic acid (NAA, $0.50 \mathrm{mg} \mathrm{1}^{-1}$ ) and, abscisic acid (BA) combined with thidiazuron (TDZ) at $0.02 \mathrm{mg} \mathrm{l}^{-1}$ and $1 \mathrm{mg} \mathrm{l}^{-1}$, respectively. Regeneration: the rooting process was on MS1/2 and one time changed to Vermiculite with the modified nutrient solution (Artigas, 2015). The replications were 
20 per medium. All processes were performed under 16 $\mathrm{h}$ light $/ 8 \mathrm{~h}$ dark at $28{ }^{\circ} \mathrm{C}$ as photoperiod in the growth chamber. During 16 weeks, the embryogenesis process was evaluated from the explant induction to regenerated plants. The secondary embryogenesis somatic or cyclic embryogenesis was done 8 times per 20 replications.

\section{Microscopic examination and morpho-ana- tomical characterization of somatic embryos}

Tissue samples were taken for the anatomical study at each developmental stage from the leaf sections and cotyledon segments, including the embryogenic and organogenic callus. The somatic embryos obtained in the process were fixed in $70 \%$ isopropyl alcohol. Consequently, the samples were embedded in paraffin (Johansen, 1940) and cut by a rotatory microtome (Valencia, Carabobo-Venezuela) into serial sections (3-10 $\mu \mathrm{m}$ thick), then stained with orcein and/or safranin. Photographic records of the morphology and histological sections were done with a stereoscopic microscope (DFC 280, Leica MZ75, Leica Microsystems, Heerbrugg, Switzerland) and a light microscope (Leica DM1000, Leica Microsystems, Wetzlar, Germany).

\section{Results}

\section{Morphological responses of the induction process}

The morphogenetic responses of $A$. indica callus cultures such as the embryogenic, organogenic, rhizogenic and non-embryogenic callus lines were obtained successfully, especially in cotyledons. This study principally characterized the primary and secondary somatic embryos. The embryogenesis and regeneration processes were obtained effectively and continuously during 16 weeks. In the previous report, the frequencies indicated differential responses between the type of explant, growth regulators (concentration and combination) and callus formed (Artigas and Fernández da Silva, 2015). However, the formation of secondary embryos was observed continuously and asynchronously. BAP at $2.5 \mathrm{mg}^{-1}$ induces $77 \%$ pri- mary embryos and $43 \%$ of secondary somatic embryos obtained. Additionally, TDZ and BA produced 57\% primary somatic embryos and $33 \%$ of the secondary type.

\section{Morpho-anatomical characterization of somatic embryogenesis process}

Two types of $A$. indica callus were successfully induced from the leaf explants. Non-embryogenic callus (NE) and rhizogenic callus (RC) in the leaf sections (Fig. 1) had a granular or gelatinous appearance with or without stimulation of organogenesis. Roots and shoots (St) were developed by indirect organogenesis as rhizogenic callus (RC). Similarly, non-embryogenic callus (NE) or friable callus (CF) were observed. These responses were influenced by the presence of BAP alone or combined. The calli were induced from leaf sections of leaflets sections (at 10 days into the culture) and large necrotic cells were developed in the greenish bulging section (Fig. 1A, B), demonstrating initially a yellowish-white, granular or friable (CF) light-gelatinous texture (Fig. 1C). In the elapsed time, the callus became necrotic (Fig. 1D) or differentiated in roots (Fig. 1E). The callus presented loosely distributed, small, irregularly shaped cells and poor cytoplasm (Fig. 1F), whereas the differentiated roots consisted of vascular tissue with xylem vessels of reticular thickenings (Fig. 1G) and abundant root hairs (Fig. 1H).

Furthermore, the cotyledon induction was substantial. The embryogenic callus (EC), organogenic callus and non-embryogenic callus (NE) were acquired. The morphological characteristics of the cotyledon segments changed after 15 days in the culture medium. Initially, the explants showed swelling in the tissue and callus formation on the cutting zones of the abaxial surface of the cotyledon, as shown in Figure 2. The formed callus can be of two types: 1) non-embryogenic (NE), similar to what has been described for the leaf sections (Fig. 1F), or Fig. 2) embryogenic callus (EC), which had a compact appearance, smooth surface and yellow-green-cream coloration. The formed calli were characterized by isodiametric cells, which were organized in a compact form with thick walls. The embryos origin was by the division of spongy and 

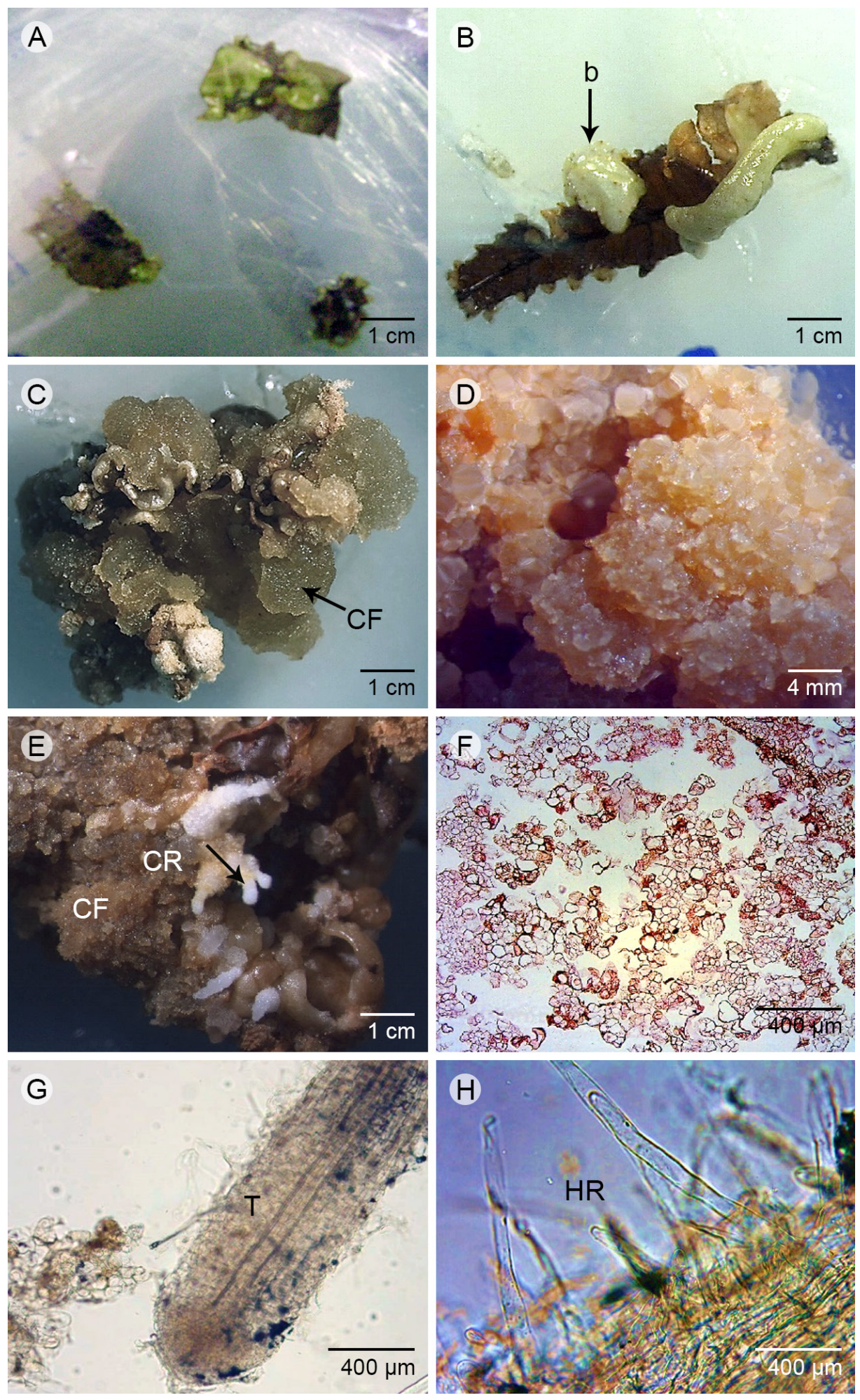

Figure 1: Morphology and histology of the induction process in foliar sections. A. initial development of callus (10 days); B. foliar section with green bulge (b); C. abundant friable callus (CF); D. friable callus with started necrosis; E. friable callus (CF) during regeneration process with roots (root primordia, CR); F. anatomy of non-embryogenic (NE) callus with details of irregular cells broadly distributed; G. anatomy of root developed in the friable callus and the conductive tissue (T); H. radicular hairs (HR). Scale A, B, C, E: 1 cm; D: 4 mm; F, G, H: $400 \mu \mathrm{m}(400 x)$. Photos: M. D. Artigas Ramirez. 
palisade parenchyma. Consequently, the cells were distributed uniformly in a pro-embryogenic mass, in which they were differentiated in meristematic nodules or packages (Fig. 2A). The meristematic nodules could be located or not in the periphery of embryogenic callus (Fig. 2B). Successively, the somatic embryos were formed.

The primary somatic embryos showed a smooth and shiny surface, with yellow-green color after 15-30 days culture. Subsequently, a large amount of embryos were observed, principally in the globular-shape stage. Embryogenic cultures derived from embryogenic callus displayed different types of cells, either isolated or forming an aggregate in different stages such as torpedo (Fig. 2C), globular (Fig. 2D) or seedling germination stage (Fig. 2E). Similarly, some secondary embryos were distinguished at this phase. The somatic embryos were renewed in isolated form (Fig. 2F) or attached to the pro-embryogenic mass (Fig. 2G), because of the presence of the connection in the parent tissue through the suspender (Fig. 2H), which evidences the origin of the embryo.

The differentiation between primary and secondary somatic embryos was demonstrated, which was continuously and asynchronously, because of the occurrence of embryos in various developmental stages. The secondary somatic embryos originated from unique isolated or cell aggregates (Fig. 2H). The embryos with different development were observed according to the origin (multicellular or unicellular, respectively), which were distinguished perfectly by a delimited mono-stratified epidermis composed of tabular cells. The secondary somatic embryos (ESS) developed during the regenerative process whereby somatic embryos are originated from primary somatic embryos. This was characterized by agglomeration of somatic embryos at different stages (globular, heart, torpedo), followed by germination of the embryos and development of the plumule (shoot), as shown in Figure 3. These results proved the synchrony of the regenerative process under the combination of BAP at high concentration. However, the asynchrony of the secondary somatic embryogenesis was differentiated because several embryos were grown at different stage of culture, especially during the regener- ation induction; for example after 6 weeks, some embryos were observed during germination or regeneration stage (Fig. 3). Similarly, these ESS were observed indirectly or directly, as well as the synchrony embryogenesis.

The ESS were observed directly at diverse phases of development. The formation of secondary somatic embryos developed directly by cell division at the epidermal and sub-epidermal levels in the primary embryos (Fig. $3 \mathrm{~A}$ ) or the regenerated organ as shoot (Fig. 3B). Additionally, during the regeneration process the ESS were differentiated directly in the hypocotilar zone (epidermal surface) of the primary somatic embryos, both non-germinated and germinated (Fig. 3C). Germinated embryos were distinguished by the observation of the elongated cells at the base of embryos and the presence of lignin in the wall in which lignin is characteristic of the development of vascular tissue. Some somatic embryos were developed in the primordia of the regenerated callus (Fig. 3D). Repetitively, the embryos continued to develop up to 8 weeks ( 4 or more cycles) as shown in Fig. 3E. This was related to the incubation period, the embryogenic response increased as the incubation time was increasing. The frequency of secondary embryos per primary somatic embryo in every cycle was $14( \pm 1)$. After 5-6 weeks, the somatic embryos could be differentiated and subsequently the plants developed the leaves and shoot. Consequently, the vitro plants were changed to MS1/2 for rooting, as shown in Fig. 3F (plants after 16 weeks). Then the plantlets were acclimated in vermiculate at $16 \mathrm{~h}$ light $/ 8 \mathrm{~h}$ dark at $28{ }^{\circ} \mathrm{C}$ as photoperiod with $60 \%$ moisture.

Some differences between the secondary and primary embryos were observed, such as the color change from light-green to light-brown, after being introduced in the storage or regeneration medium (Fig. 3A). Nonetheless, some deformation was present in several calli during the embryogenic process, which was proportional to the concentration of growth regulator used. The effect of BAP was less evident than that of TDZ in the same phase. Nonetheless, by combining NAA with BAP the deformation was more pronounced, and some calli became necrotic, in the same way as those obtained from leaves (Fig. 1F). 

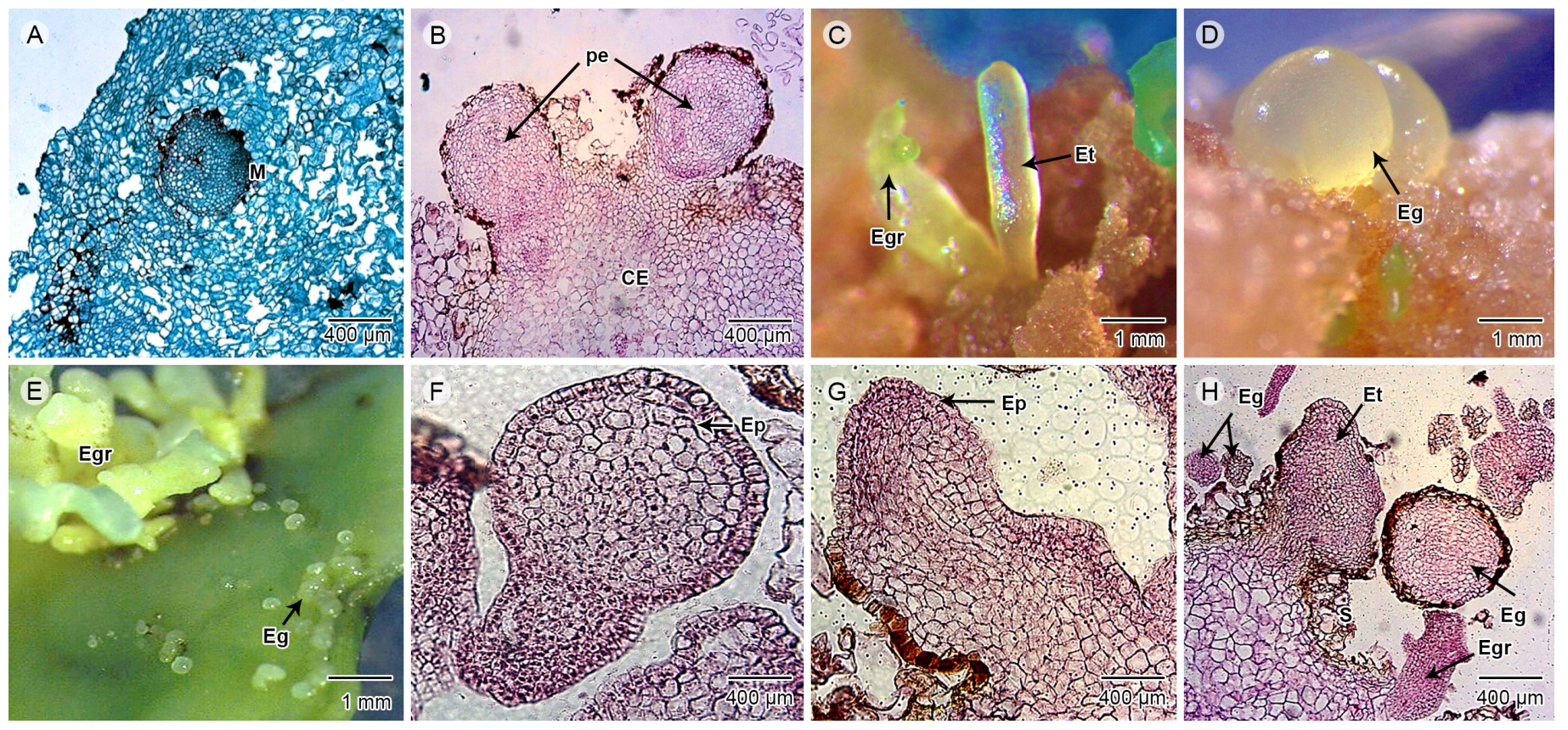

Figure 2: Morpho-anatomical characterization of somatic embryogenesis in cotyledons sections. A. differentiation of meristematic nodule (M) comprised a callus mass with isodiametric cells; B. pro-embryos (pe) located in the periphery of callus (CE); C. torpedo embryos (Et) and germinating embryos (Egr); D. globular embryos (Eg) emerged from callus; E. grouping of Eg and Egr; F. somatic embryo with a unicellular origin which was attached by a suspensor from the epidermis (Ep); G. torpedo embryo attached to the pro-embryogenic mass and showed Ep; H. detail of agglomeration at different stages of embryos such as Eg, Egr, Et and Suspender (S). Scale A, B, F, G, H: 400 $\mu$ m (400×); C, D, E: $1 \mathrm{~mm}$. Photos: M. D. Artigas Ramirez.

\section{DISCUSSION}

The embryogenic, organogenic and non-embryogenic callus lines were successfully obtained and characterized. The morphogenetic findings indicated a differential response, with respect to the callus formation and differentiation of somatic embryos between primary and secondary ones, according to the explant type and the growth regulators (concentration and combination), as described by Artigas and Fernández da Silva (2015) and other reports in Meliaceae species (Capote and Estrada, 2001; Ranjan, 2005; Vila et al., 2009). The non-existent response of embryogenesis somatic in the leaflet sections was due to the high cell differentiation of veins and leaflet midvein. Some forest species present vascular tissue that favors organogenesis (Vila et al., 2003), due to the transport of endogenous hormones through these conductive tissues (Miriam et al., 2008). The different responses in the leaflet sections were mainly influenced by the presence of BAP alone or combined with cytokinins or auxins (Capote and Estrada, 2001; Ranjan, 2005). Generally, Meliaceae species have achieved embryogenic callus from cotyledons under the combination of NAA $\left(3 \mathrm{mg} \mathrm{l}^{1^{-1}}\right)$ and BAP $\left(1 \mathrm{mg} \mathrm{l}^{-1}\right)$, as indicated by Sharry and Teixeira (2006). However, our results showed that this combination was not favorable because a large amount of callus was not embryogenic (NE) in cotyledons. The calli of leaf sections showed a high level of necrosis, caused by the contact of explants with disinfecting solutions (Vila et al., 2003; 2004). Additionally, these results might be influenced by the exposition of the donor plants to the environmental factors and pollutants (abiotic and biotic), which affected callus development and promoted the proliferation of exogenous and endogenous pathogens on the explants (Vila et al., 2004). Furthermore, we suggested that the secondary somatic embryogenesis was associated with the age and physiological condition of the explant. 

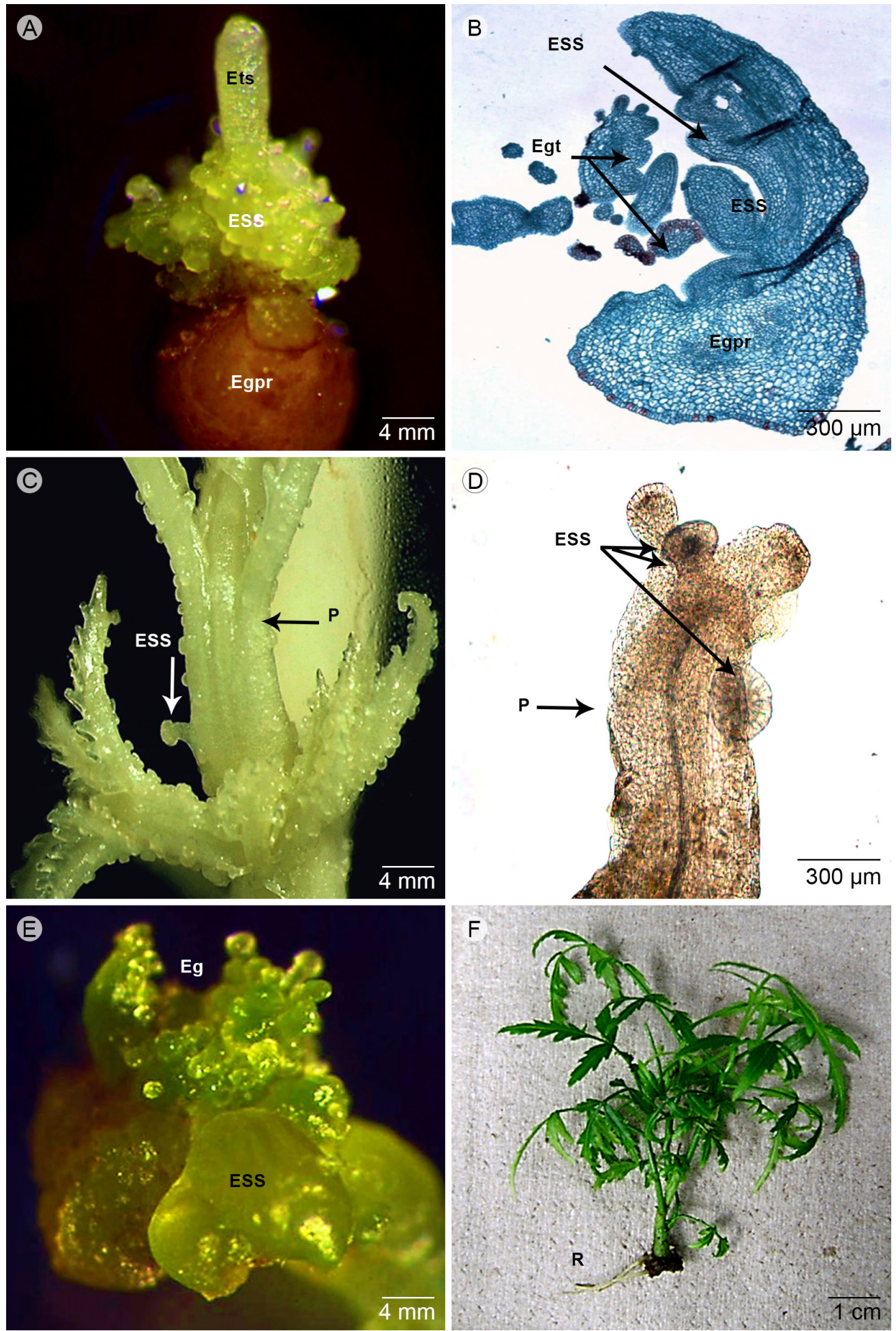

Figure 3: Morpho-histological characterization of asynchronous somatic embryogenesis. A. differentiation of secondary somatic embryos (ESS, included torpedo embryo secondary - Ets) originated directly from the primary embryo (Egpr); B. agglomeration of somatic embryos at different stages as globular embryos germinating (Egpr) and ESS emerging directly from the epidermis, as well as tertiary globular embryos (Egt); C. a large amount of ESS originated directly from primordia of shoot $(\mathrm{P})$ regenerated from primary somatic embryos; D. anatomy aspect of primordia shoot (P) with ESS; E. somatic embryos with ESS developed directly in the fourth cycle (contained abundant Eg); F. vitro plants developed after 2 weeks in the rooting (R) culture (MS 1/2). Scale A, C, E: 4 mm; B, D: $300 \mu \mathrm{m}(400 \times)$; F: 1 cm. Photos: M. D. Artigas Ramirez. 
Accordingly, the morpho-anatomical response was related to the type, developmental level and genotype of the explants (Chaturvedi et al., 2004; Vila et al., 2005). However, the development and maturation of the embryos were successfully completed from the cotyledon sections, in response to the highest amount of BAP or especially to the external level of auxins.

The embryogenic callus and friable were found in the cotyledon segments, suggesting that the pericarp protects the cotyledon against some environmental factors or disinfection treatment. In addition, the abundant reserve substances from cotyledon tissue help the induction of embryogenic callus and whole plant regeneration (Gairi and Rashid, 2004; Thomas and Chaturdevi, 2008; Srivastava et al., 2009). Researchers who have worked with Meliaceae species suggested that somatic embryogenesis was obtained from certain pro-embryogenic cells without the presence of auxin in the culture medium, such as 2.4-Dichlorophenoxyacetic acid (Sharry and Teixeira, 2006). Moreover, the location of the meristematic nodule formation differed by the exposition of explants to an enriched-cytokinins medium (Shrikhande et al., 1993; Parrott, 2002; Chaturvedi et al., 2003; Thomas and Chaturdevi, 2008). Consequently, the rupture of plasmodesmata led to the isolation of a cell or groups of cells and formation of the pro-embryos. A large amount of the pro-embryogenic mass was a prerequisite for the subsequent proliferation and high-frequency differentiation of somatic embryos (Parrott, 2002; Chaturvedi et al., 2003; Chaturdevi et al., 2004; Thomas and Chaturvedi, 2008). The primary somatic embryos were observed in the periphery mass after 30 days; those embryos were next to the mass or attached through a suspensor, which revealed the origin of the somatic embryos that can be multicellular or unicellular (Parrott, 2002; Morimoto et al., 2006; Sharry et al., 2006; Singh and Chaturvedi, 2009). Therefore, $A$. indica developed primary somatic embryos with only BAP at $1 \mathrm{mg} \mathrm{l}^{-1}$ (Chaturvedi et al., 2004). However, our results under low concentrations enhanced the indirect organogenesis in detriment of somatic embryogenesis, which suggests that high concentrations of cytokinin are required. The cytokinin effects are significant and may become mandatory for the differentiation of primary and secondary somatic embryos (Parrott, 2002; Indieka et al., 2007; Miriam et al., 2008). On the other hand, the TDZ is an effective synthetic growth regulator as a successful alternative to direct high-frequency regeneration of somatic embryos, because it could replace the level of auxin or cytokinin required for induction and proliferation of somatic embryos (Visser et al., 1992; Raemakers et al., 1995). The TDZ-effect brings uncertainty because of the relationship between the explants and endogenous auxin/ cytokinin concentration is still unclear.

The occurrence of both multicellular and unicellular origins of somatic embryos are considered a common phenomenon (Gairi and Rashid, 2005; Mulanda et al., 2014). However, the primary embryos with multicellular origin were more frequent. The secondary somatic embryos originated directly from sub-epidermal and epidermal cells in the hypocotilar zone of primary embryos, as Fernández et al. (2005) described in Coffea arabica L. Generally, there are two types of embryos: the unicellular embryos that are distinguished for being attached to the parental tissue by suspensor-like structures (Simoes, et al., 2010), while multicellular embryos do not have the suspensor connecting the callus mass and embryos (Quiroz et al., 2006). Embryos can be originated directly from a simple embryogenic cell or from a multicellular complex. The embryos originated from a simple cell were located at the periphery of the callus. Moreover, the embryos cleaved in the multi-embryonal complex had a unicellular origin, which was formed by polyembryonic excision of the cells (Haccius and Bhandari, 1975).

The secondary somatic embryogenesis, called cyclic or repetitive embryogenesis, which is a base of the massive clonal reproduction of many plant species as Dianthus caryophyllus L. (Karami et al., 2008), Solanum nigrum L. (Nair and Gupta, 2006), Morus alba L. (Agarwal et al., 2004), Phalaenopsis amabilis L. (Chen and Chang, 2004), Arachis hypogaea L. (Chengalrayan et al., 2001), Medicago truncatula Gaertn. (Das Neves et al., 1999), Myrtus communis L. (Parra and Amo-Mar- 
co, 1998), M. azedarach L. (Sharry and Teixeira, 2006) and Coffea arabica (Fernández et al., 2005). Singh and Chaturvedi (2009) previously reported the frequencies of somatic embryogenesis in A. indica. Therefore, this study included full histological details for cycle somatic embryogenesis.

The development of primary and secondary somatic embryos were evidenced continuously and asynchronously, because the embryos were developed in various stages at the same time as described for Cedrela fissilis Vell. (Vila et al., 2009), Sorbus pohuashanensis (Hance) Hedl. (Yang et al., 2012) and A. indica (Shrikhande et al., 1993; Murthy and Saxena, 1998). In contrast, the secondary embryos originated directly in the subepidermal and epidermal cells of the hypocotilar area from primary somatic embryos as described by Fernández et al. (2005). In this work, an uninterrupted cycling of somatic embryogenesis was observed due to consecutive exposure to growth regulators. These results were demonstrated by the formation of primary somatic embryos to tertiary o more embryos (Raemakers et al., 1995). The report from Parrott (2002) and our present results suggested that the external auxin concentration could interfere with the normal histo-differentiation, because when the auxin level is an over-low threshold in the culture medium, the embryogenic cells begin a histodifferentiation process and prevent the acquisition of bilateral symmetry and apical meristem development. The secondary embryos grow from a primary embryo during the maturation process (Chaturdevi et al., 2004). It occurred when the endogenous level of auxins reached the optimum limit (Parrott, 2002). Hence, A. indi$c a$ has been reported as one of tree species that had a high concentration of auxins. Furthermore, the level of exogenous auxin should be less than the limit; otherwise, the embryogenesis cycle could break and develop into mature embryos (Parrott, 2002; Jiménez, 2005; Simoes et al., 2010). The embryogenic tissues and amount of embryos with high regenerative abilities enable a large-scale of multiplication and an unlimited production of propagules, which could germinate and produce entire plants. It is important to mention that the acquisition of competent and suitable embryogenic somatic cells must involve some modifications, changes or reprogramming of patterns in the morphology, physiology, metabolism or gene expression (Simoes et al., 2010), which need further studies at molecular level.

The regeneration system of Meliaceae species by organogenesis has been obtained in Melia azedarach (Vila et al., 2005) with BAP, Toona ciliata M. Roem. at $0.1 \mathrm{mg} \mathrm{l}^{-1} \mathrm{TDZ}$ (Daquinta et al., 2005) and Actinidia deliciosa (A. Chev.) C.F. Liang \& A.R. Ferguson with $0.5 \mathrm{mg}$ $1^{-1}$ TDZ (Goralski et al., 2005, Popielarska et al., 2006). On the other hand, the direct somatic embryogenesis has been obtained from shoots with only cytokinins; however, there are differences between primary and secondary embryos using $1 \mathrm{mg} \mathrm{l}^{-1} \mathrm{BAP}$, or combined with auxins or other cytokinins (Te-Chato and Rungnoi, 2000; Giagnacovo et al., 2001; Chaturvedi et al., 2004; Morimoto et al., 2006). Moreover, other authors indicated that the use of low concentrations of auxins promoted regenerative organogenic callus and high concentrations induced the formation of non-regenerative calli in $A$. indica (Wen Su et al., 1997; Kota et al., 2006; Shekhawat et al., 2009; Das, 2011) and Melia azedarach (Deb, 2001; Sharry and Teixeira, 2006). According to these, the abnormalities found in our studies were consequences of the injuries level in the explants or due to the long exposition with exogenous growth regulators.

In the regeneration medium tested in this research, the carbon source was sucrose $3 \%$, which allowed the germination and regeneration of somatic embryos. We determined that the high carbon concentration affected the development of roots (Shrikhande et al., 1993). The total omission of growth regulators in the culture media allowed the transference of embryos for development into whole plants (Indieka et al., 2007; Vila et al., 2009, Peña-Ramirez et al., 2011; Mulanda et al., 2014). These results contrasted those presented by Singh and Chaturvedi (2009), which only obtained $10 \%$ germination demonstrating no secondary somatic embryos devoid of growth regulators means. Based on MS1/2-rooting medium, $86.67 \%$ of regenerated plants were from somatic embryos 
(obtained directly), which developed one to three functional roots in a period of 15-20 days in this condition.

Finally, the somatic embryos were induced indirectly or directly in five weeks. Hence, the process was characterized by the induction until the regeneration. Hence, somatic embryos were successfully characterized at different stages. The morpho-anatomical characterization showed an efficient in vitro protocol for regeneration by secondary somatic embryogenesis of $A$. indica, which may be applied to other recalcitrant species. Additionally, the somatic embryogenesis is contributing to the implementation of clonal forestry; the establishment of this efficient system offers the opportunity to obtain potentially elite cell lines, particularly secondary embryogenesis. The culture system established could be used to improve the productivity and to enhance wood to optimize the secondary metabolite production, such as azadirachtin, through cell suspension or other protocols.

\section{FUNDING}

This work was supported by The Council for Scientific and Humanistic $(\mathrm{CDCH})$ of the University of Carabobo (UC), Special Research Fund CDCH-VAC-259-09 - Venezuela.

\section{AUTHOR CONTRIBUTION}

MDAR performed the analyses of samples and acquisition of data. The interpretation of data was done by RF and MDAR. Both authors contributed to experimental design, manuscript writing, discussion, revision and approval of the final manuscript.

\section{ACKNOWLEDGMENTS}

The Council for Scientific and Humanistic $(\mathrm{CDCH})$ of the University of Carabobo (UC, Venezuela) for funding this work, as well as the entire staff of the Center of Applied Biotechnology (CBA) of the UC, Venezuela.

\section{LITERATURE CITED}

Agarwal, S., K. Kanwar and D. R. Sharma. 2004. Factors affecting secondary somatic embryogenesis and embryo maturation in Morus alba L. Scientia Horticulturae 102(3): 359-368. DOI: http://dx.doi.org/10.1016/j. scienta.2004.04.002

Akula, C., A. Akula and R. Drew. 2003. Somatic embryogenesis in clonal neem, Azadirachta indica A. Juss. and analysis for in vitro azaridachtine production. In vitro cellular and Developmental Biology-Plant 39(3): 304-310. DOI: http://dx.doi.org/10.1079/IVP2003415

Alcalá, M., N. Vargas and A. Pire. 2005. Efecto de extractos vegetales y fungicidas sintéticos sobre el crecimiento micelial in vitro de Sclerotium rolfsii y Thielaviopsis basicola. Revista de la Facultad de Agronomía 22(4): 315-323.

Allan, E., T. Stuchbury and A. Mordue. 1999. Azadirachta indica A. Juss (Neem tree), In vitro culture, micropropagation and the production of Azaradichtin and other secondary metabolites. Biotechnology in Agriculture and Forestry 43: 11-41. DOI: http://dx.doi.org/10.1007/978-3-66208614-8_2

Artigas, R. M. D. 2015. Characterization of rhizobium isolated from different agro-ecological conditions of Venezuela. Master Thesis. Department of Biological Production Science, United Graduated School of Agriculture Science, Tokyo University of Agriculture and Technology (TUAT). Tokyo, Japan. 169 pp.

Artigas, R. M. D. and R. Fernández Da Silva. 2015. Establecimiento del sistema de regeneración por embriogénesis somática de Azadirachta indica A. Juss. Acta Biológica Colombiana 20(2): 73-83. DOI: http://doi. org/10.15446/abc.v20n2.44200.

Badu, V., S. Narasimham and G. Nair. 2006. Bioproduction of Azadirachtin-A, Nimbin and Salannin in callus and cell suspension cultures of Neem (Azadiractha indica A. Juss). Current Science 91(1): 22-24.

Capote Rodríguez, A. and J. Estrada Ortiz. 2001. Propagación in vitro del nim (Azadirachta indica A. Juss.) mediante brotes axilares. Revista Ciencia Forestal en México 26(90): 103-113.

Chaturvedi, R., M. K. Razdan and S. Bhojwani. 2003. An efficient protocol for the production of triploid plants from endosperm callus of neem, Azadirachta indica A. 
Juss. Journal of Plant Physiology 160(5): 557-564. DOI: http://doi.org/10.1078/0176-1617-00884

Chaturvedi, R., M. K. Razdan and S. S. Bhojwani. 2004. In vitro morphogenesis in zygotic embryo cultures of neem (Azadirachta indica A. Juss). Plant Cell Reports 22(11): 801-809. DOI: http://doi.org/10.1007/s00299004-0768-0

Chen, J. T. and W. C. Chang. 2004. Induction of repetitive embryogenesis from seed-derived protocorms of Phalaenopsis amabilis var. formosa Shimadzu. In vitro cellular and Developmental Biology-Plant 40(3): 290293. DOI: http://doi.org/10.1079/IVP2003527

Chengalrayan, K., S. Hazra and M. Gallo-Meagher. 2001. Histological analysis of somatic embryogenesis and organogenesis induced from mature zygotic embryoderived leaflets of peanut (Arachis hypogaea L.). Plant Science 161(3): 415-421. DOI: http://dx.doi.org/10.1016/ S0168-9452(01)00439-3

Daquinta, M., Y. Lezcano, M. Cid, D. Pina and R. Rodríguez. 2005. Morfogénesis in vitro de Toona ciliata a partir de raquis de hojas jóvenes con tidiazuron. Revista Colombiana de Biotecnología 7(2): 5-9.

Das, P. 2011. In Vitro Somatic Embryogenesis in some oil yielding tropical tree species. American Journal of Plant Sciences 2(2): 217-222. DOI: http://doi.org/10.4236/ ajps.2011.22023

Das Neves, L. O., S. R. L. Duque, J. S. de Almeida and P. S. Fevereiro. 1999. Repetitive somatic embryogenesis in Medicago truncatula ssp. narbonensis and M. truncatula Gaertn. cv. Jemalong. Plant Cell Reports 18(5): 398-405. DOI: http://doi.org/10.1007/s002990050593

Deb, C. R. 2001. Somatic Embryogenesis and Plantlet Regeneration of Melia azedarach L. (Ghora Neem) from cotyledonary segments. Journal of Plant Biochemistry and Biotechnology 10(1): 63-65. DOI: http://doi.org/10.1007/ BF03263110

Fernández Da Silva, R., A. Villarroel, L. Cuamo and V. Storaci. 2016. Evaluación de un sistema de regeneración por embriogénesis somática de Neem (Azadirachta indica). Acta Biológica Colombiana 21(3): 581-592. DOI: http:// doi.org/10.15446/abc.v21n3.52626
Fernández Da Silva, R., L. Hermoso-Gallardo and A. Menéndez-Yuffá. 2005. Primary and secondary somatic embryogenesis in leaf sections and cell suspension of Coffea arabica cv. Catimor. Interciencia 30(11): 694-698.

Gairi, A. and A. Rashid. 2004. Direct differentiation of somatic embryos on different regions of intact seedlings of Azadirachta in response to Thidiazuron. Journal of Plant Physiology 161(9): 1073-1077. DOI: http://doi. org/10.1016/j.jplph.2004.05.001.

Gairi, A. and A. Rashid. 2005. Direct differentiation of somatic embryos on cotyledons of Azadirachta indica. Biologia Plantarum 49(2): 169-173. DOI: http://doi.org/10.1007/ s10535-005-0173-8.

Gautam, V. K., K. Nanda and S. C. Gupta. 1993. Development of shoots and roots in anther-derived callus of Azadirachta indica A. Juss.-a medicinal tree. Plant Cell, Tissue and Organ Culture 34(1): 13-18. DOI: http://doi.org/10.1007/ BF00048458.

Van der Esch, S. A., O. Maccioni, F. Vitali, G. Giagnacovo, G. Pasqua and B. Monacelli. 2001. Organogenesis and embryogenesis from callus cultures of Azadirachta excelsa. Plant Biosystematics-An International Journal Dealing with all Aspects of Plant 135(1): 13-18. DOI: http://doi.org/10.1080/11263500112331350590.

Góralski, G., M. Popielarska, H. Śesak, D. Siwińska and M. Batycka. 2005. Organogenesis in endosperm of Actinidia deliciosa cv. Hayward cultured in vitro. Acta Biologica Cracoviensia Series Botanica 47(2): 121-128.

Haccius, B. and N. Bhandari. 1975. Delayed histogen differentiation as a common primitive character in all types of non-zygotic embryos. Phytomorphology 25: 91-94.

Indieka, S., D. Odee, G. Muluvi, K. Rao and J. Machuka. 2007. Regeneration of Melia volkensii Gürke (Meliaceae) through direct somatic embryogenesis. New Forests 34(1): 73-81. DOI: http://doi.org/10.1007/s11056-0079038-7.

Isman, M. B., O. Koul, A. Luczynski and J. Kaminski. 1990. Insecticidal and antifeedant bioactivities of neem oils and their relationship to Azadirachtin content. Journal of Agricultural and Food Chemistry 38(6): 1406-1411. DOI: http://doi.org/10.1021/jf00096a024 
Jiménez, V. M. 2005. Involvement of plant hormones and plant growth regulators on in vitro somatic embryogenesis. Plant Growth Regulation 47: 91-110. DOI: http://doi. org/10.1007/s10725-005-3478-x

Johansen, S. 1940. Plant Microtechnique. Mc Graw-Hill Book Company. New York, USA. 523 pp.

Karami, O., A. Deljou and G. K. Kordestani. 2008. Secondary somatic embryogenesis of carnation (Dianthus caryophyllus L.). Plant Cell, Tissue and Organ Culture 92(3): 273-280. DOI: http://doi.org/10.1007/s11240-007-9332-2

Kota, S., R. Rao and P. Chary. 2006. In vitro response of select regions of Azadirachta indica A. Juss (Meliaceae) as elucidated by biochemical and molecular variations. Current Science 91(6): 770-776.

Kundu, S. 1999. The mating system and genetic significance of polycarpy in the neem tree (Azadirachta indica). TAG Theoretical and Applied Genetic 99(7-8): 1216-1220. DOI: http://dx.doi.org/10.1007/s001220051327

LUZ. 2001. Neem, un árbol milagroso. Facultad de Agronomía, Universidad del Zulia. Maracaibo, Venezuela. 49 pp.

Meisner, J., K. R. S. Ascher, R. Aly and J. D. Warthen. 1981. Response of Spodoptera littoralis (Boisd.) and Earias insulana (Boisd.) larvae to azadirachtin and salannin. Phytoparasitica 9(1): 27-32. DOI: http://dx.doi. org/10.1007/BF03158326

Morgan, D. E. 2009. Azadirachtin, a scientific gold mine. Bioorganic and Medicinal Chemistry 17(12): 4096-4105. DOI: http://dx.doi.org/10.1016/j.bmc.2008.11.081

Morimoto, M., K. Nakamura and H. Sano. 2006. Regeneration and genetic engineering of a tropical tree, Azadirachta excelsa. Plant Biotechnology 23(1): 123-127. DOI: http:// doi.org/10.5511/plantbiotechnology.23.123

Mulanda, E. S., M. Adero, D. Wepukhulu, N. Amugune, E. Akunda and J. Kinyamario. 2014. Thidiazuron-induced somatic embryogenesis and shoot regeneration in cotyledon explants of Melia volkensii Gürke. Propagation of Ornamental Plants 14(1): 40-46.

Murthy, B. and P. Saxena. 1998. Somatic embryogenesis and plant regeneration of neem (Azadirachta indica A. Juss). Plant Cell Reports 17(6-7): 469-475. DOI: http://doi. org/10. 1007/s002990050427.
Nair, R. R. and S. Dutta Gupta. 2006. High-frequency plant regeneration through cyclic secondary somatic embryogenesis in black pepper (Piper nigrum L). Plant Cell Reports 24(12): 699-707. DOI: http://doi. org/10.1007/s00299-005-0016-2

Parra, R. and J. Amo-Marco. 1998. Secondary somatic embryogenesis and plant regeneration in myrtle (Myrtus communis L.). Plant Cell Reports 18(3-4): 325-330. DOI: http://doi.org/10.1007/s002990050580

Parrott, W. 2002. La embriogénesis somática en las angiospermas. VI Simposio Internacional de Biotecnología Vegetal. Instituto de Biotecnología de Las Plantas. Villa Clara, Cuba. Pp. 7-17.

Parrotta, J. A. and A. N. Chaturvedi. 1994. Azadirachta indica A. Juss. Neem, margosa. Meliaceae. Mahogany family. USDA Forest Service, International Institute of Tropical Forestry SO-ITF-SM-70. Los Angeles, USA. 8 pp.

Pastelín-Solano, M. C., M. C. López Peralta, Y. Martínez Ocampo, T. González Arnao, D. A. Rodríguez-Lagunes and O. Castañeda. 2008. Germinación in vitro del neem (Azadirachta indica A. Juss) y regeneración de múltiples brotes. Instituto Nacional de Investigaciones Forestales, Agrícolas y Pecuarias (INIFAP); Universidad Veracruzana (UV); Colegio de Postgraduados (CP); Universidad Autónoma de Chapingo (UACH); Instituto Tecnológico de Ursulo Galván (IUTG); Instituto Tecnológico de Boca del Río (ITBOCA). Avances en la Investigación Agrícola, Pecuaria, Forestal y Acuícola en el Trópico Mexicano, Libro Científico 6. Veracruz, México. pp. 267-275.

Peña-Ramírez, Y., I. García-Sheseña, A. Hernández-Espinoza, A. Domínguez-Hernandez, F. Barredo-Pool, J. GonzálezRodríguez and M. L. Robert. 2011. Induction of somatic embryogenesis and plant regeneration in the tropical timber tree Spanish red cedar (Cedrela odorata L. (Meliaceae)). Plant Cell, Tissue and Organ Culture 105(2): 203-209. DOI: http://doi.org/10.1007/s11240010-9853-y

Pietrosemoli, S., R. Olavez, T. Montilla and Z. Campos. 1999. Empleo de hojas de Neem (Azadirachta indica A. Juss) en control de nemátodos gastrointestinales de bovinos a 
pastoreo. Revista de la Facultad de Agronomía 1(supl.1): 220-225.

Popielarska, M., H. Slesak and G. Góralski. 2006. Histological and SEM studies on organogenesis in endosperm-derived callus of Kiwifruit (Actinidia deliciosa cv. Hayward). Acta Biologica Cracoviensia Series Botanica 48(2): $97-$ 104.

Puri, H. S. 1999. Neem: The Divine Tree. Azadirachta indica. Harwood Academic Publishers CRC Press. Amsterdam, Netherlands. 196 p.

Quiroz-Figueroa, F., R. Rojas-Herrera, R. Galaz-Avalos and V. Loyola-Vargas. 2006. Embryo production through somatic embryogenesis can be used to study cell differentiation in plants. Plant Cell, Tissue and Organ Culture 86: 285-301. DOI: http://doi.org/10.1007/S11240-006-9139-6

Raemakers, C. J. J. M. , E. Jacobsen and R. F. G. Visser. 1995. Secondary somatic embryogenesis and applications in plant breeding. Euphytica 81(1): 93-107. DOI: http://doi. org/10.1007/BF00022463

Ranjan, G. R. 2005. In vitro somatic embryogenesis in callus cultures of Azadirachta indica A. Juss.-a multipurpose tree. Journal of Forest Research 10(4): 263-267. DOI: http://doi.org/10.10.1007/s10310-004-0130-y

Sharry, S. and J. Teixeira Da Silva. 2006. Effective organogenesis, somatic embryogenesis and salt tolerance induction in vitro in the Persian lilac tree (Melia azedarach L.). Floriculture, Ornamental and Plant Biotechnology 2: 317-324.

Sharry, S., J. L. Cabrera, L. Herrera, R. M. Rangel, S. Lede and W. Abedini. 2006. An alternative pathway for plant in vitro regeneration of chinaberry -tree Melia azedarach L. derived from the induction of somatic embryogenesis. Electronic Journal of Biotechnology 9(3): 188-194. DOI: http://doi.org/10.2225/vol9-issue3-fulltext ${ }^{-13}$

Shekhawat, G. S., S. Mathur and A. Batra. 2009. Role of phytohormones and nitrogen in somatic embryogenesis induction in cell culture derived from leaflets of Azadirachta indica. Biologia Plantarum 53(4): 707-710. DOI: http://doi.org/10.1007/s10535-009-0127-7

Shrikhande, M., S. Thengane and A. Mascarenhas. 1993. Somatic embryogenesis and plant regeneration in
Azadirachta indica A. Juss. In vitro Cellular and Developmental Biology-Plant 29(1): 38-42. DOI: https:// doi.org/10.1007/BF02632237

Simões, C., N. Albarello, C. Henriques Callado, T. Carvalho de Castro and E. Mansur. 2010. Somatic embryogenesis and plant regeneration from callus cultures of Cleome rosea Vahl. Brazilian Archives of Biology and Technology 53(3): 679-686.

Singh, M. and R. Chaturvedi. 2009. An efficient protocol for cyclic somatic embryogenesis in Neem (Azadirachta indica A. Juss). Proceedings of World Academy of Science Engineering and Technology 51: 656-658.

Srivastava, P., M. Singh, P. Mathur and R. Chaturvedi. 2009. In vitro organogenesis and plant regeneration from unpollinated ovary cultures of Azadirachta indica. Biologia Plantarum 53(2): 360-364. DOI: http://doi. org/10.1007/s10535-009-0067-2

Sutherland, J., V. Baharally and D. Permaul. 2002. Use of the botanical insecticide, neem to control the small rice stinkbug Oebalus poecillus (Dallas, 1851) (Hemiptera: Pentatomidae) in Guyana. Entomotropica 17(1): 97-101.

Capataz Tafur, J., F. Orozco Sánchez, R. Vergara Ruiz and R. Hoyos Sánchez. 2007. Efecto antialimentario de los extractos de suspensiones celulares de Azadirachta indica sobre Spodoptera frugiperda J. E. Smith en condiciones de laboratorio. Revista Facultad Nacional de Agronomía, Medellín 60(1): 3703-3715.

Te-Chato, S. and O. Rungnoi. 2000. Induction of somatic embryogenesis from leaves of Sadao Chang (Azadirachta excelsa (Jack) Jacobs). Scientia Horticulturae 86(4): 311321. DOI: http://doi.org/10.1016/S0304-4238(00)00153-9

Thomas, T. and R. Chaturvedi. 2008. Endosperm culture: a novel method for triploid plant production. Plant Cell, Tissue and Organ Culture 93(1): 1-14. DOI: http://doi. org/10.1007/s11240-008-9336-6.

Tripathi, L. and J. Tripathi. 2003. Role of biotechnology in medicinal plants. Tropical Journal of Pharmaceutical Research 2(2): 243-253.

Vila, S., A. González, H. Rey and L. Mroginski. 2003. Somatic embryogenesis and plant regeneration from inmature zygotic embryos of Melia azedarach (Meliaceae). In 
Vitro Cellular Developmental Biology-Plant 39(3): 283287. DOI: http://doi.org/10.1079/IVP2002377

Vila, S. K., H. Y. Rey and L. A. Mroginski. 2004. Influence of genotype and explant source on direct organogenesis by in vitro culture of leaves of Melia azedarach L. Biocell 28(1): 35-41.

Vila, S., A. González, H. Rey and L. Mroginski. 2005. Plant regeneration, origin, and development of shoot buds from root segments of Melia azedarach L. (Meliaceae) seedlings. In Vitro Cellular Developmental Biology-Plant 41(6): 746. DOI: http://doi.org/10.1079/IVP2005692

Vila, S., H. Rey and L. Mroginski. 2009. Somatic embryogenesis and plant regeneration in Cedrela fissilis. Biologia Plantarum 53(2): 383-386. DOI: http://doi.org/10.1007/ s10535-009-0072-5

Visser, C., J. Qureshi J, R. Gill and P. Saxena. 1992. Morphoregulatory Role of Thidiazuron: Substitution of Auxin and Cytokinin Requirement for the Induction of Somatic Embryogenesis in Geranium Hypocotyl Cultures. Plant Physiology 99(4): 1704-1707. DOI: http:// doi.org/10.1104/pp.99.4.1704

Wen Su W., W. Hwang, S. Young and Y. Sagawa. 1997. Induction of somatic embryogenesis in Azadirachta indica. Plant Cell, Tissue and Organ Culture 50(2): 91-95. DOI: http://doi.org/10.1023/A:1005891113815

Wewetzer, A. 1998. Callus cultures of Azadirachta indica and their potential for the production of Azaridachtin. Phytoparasitica 26(1): 47-52. DOI: http://doi.org/10.1007/ BF02981265

Yang, L., J. Wang, L. Bian, Y. Li and H. Shen. 2012. Cyclic secondary somatic embryogenesis and efficient plant regeneration in mountain ash (Sorbus pohuashanensis). Plant Cell, Tissue and Organ Culture 111(1): 1-10. DOI: http://doi.org/10.1007/s11240-012-0181-2 